\title{
Characteristic Pattern of Aroma Ester Formation from Banana, Melon, and Strawberry with Reference to the Substrate Specificity of Ester Synthetase and Alcohol Contents in Pulp
}

\author{
Yoshinori UedA ${ }^{*}$, Atsushi Tsuda ${ }^{*}$, Jin-He BaI ${ }^{*}$, Noriyuki Fujishita ${ }^{*}$ \\ and Kazuo CHACHIN ${ }^{*}$ \\ * College of Agriculture, Univertity of Osaka Prefecture, \\ Mozu-umemachi, Sakai, Osaka 591 \\ ** Lion Corporation, Honjo, Sumida-ku, Tokyo 130
}

\begin{abstract}
Volatile esters produced from banana, melon and strawberry fruits were investigated by analyzing head-space gas. In the case of banana, ethyl and butyl esters were found to be main esters and isobutyl and isoamyl esters followed. In melon, ethyl esters were predominant, and in strawberry methyl esters were mainly observed. In all cases of these fruits, acetate and butyrate were the main esters. Alcohol acyl CoA transferase (ester synthetase) was extracted from these fruits. A high reactivity of the enzyme was observed when propyl, isobutyl, butyl and isoamyl alcohols were used as the substrates, whereas a low reactivity was observed when methyl, ethyl and amyl alcohols were used. The enzyme from banana and melon reacted well with acetyl CoA, propionyl CoA and butyryl CoA, while the enzyme from strawberry reacted well with valeryl CoA besides the above three acyl CoAs. Branched chain acyl CoAs (isobutyryl and isovaleryl) were poor substrates for the enzyme. Ethyl alcohol was predominant among alcohols observed in pulp of banana and melon fruits, whereas methyl alcohol was predominant in strawberry. From these observations, it may be concluded that esters produced from fruits have alcohol moieties reflected alcohol contents in the pulps and have acid moieties reflected acyl CoA specificity of the ester synthetase.
\end{abstract}

Volatile esters generally occupy a large part of volatile compounds emanated from fruits and some of them are important for characterizing fruits aroma, as isoamyl acetate in banana fruit. There is a characteristic ester formation depending on fruit species. Banana mainly produces esters by a combination of acetic acid and alcohols ${ }^{1)}$, while strawberry produces esters by a combination of methyl alcohol and aliphatic acids in addition to ethyl esters $^{2}$, and melon produces mainly ethyl acetate $^{3)}$. In this study, the substrate specificity of ester synthetase (alcohol acyl CoA transferase) from banana, melon and strawberry fruits, and alcohol contents in the pulp of these fruits were investigated in order to elucidate the factors which determine the characteristic formation of aroma esters.

\section{Materials and Methods}

\section{Materials}

Yellow ripened banana (cv. Cavendish) was purchased from a retail shop and further ripened at $20^{\circ} \mathrm{C}$ to an over-ripe stage showing the entire flecks. Oriental sweet melon (var. makuwa cv. Gensung) was grown at the experimental farm of University of Osaka Prefecture and harvested at the full size and yellow stage. Strawberry (cv. Hōkō-wase) was also grown at the same farm and harvested at the full red stage.

The enzyme preparation

Ester synthetase was prepared according to the method reported previously ${ }^{4}$. In brief, 
immediately after harvest (melon and strawberry) or at the overripe stage (banana), a certain amount of pulp was treated with Macerozyme R-10 (Kinki Yakult Co. Ltd.) and macerated to cell suspension. The collected cells were crushed by mortar and pestle in the presence of $0.1 \mathrm{mM}$ DTT (dithiothreitol) and 1 $\%(w / v)$ PVP (polyvinyl-pyrrolidone), and by centrifugation at $12000 \mathrm{~g}$ for $30 \mathrm{~min}$. The protein in cell free extracts was precipitated by ammonium sulfate. Eighty percent saturation of the salt was used for the precipitation with the banana and strawberry extracts and $40 \%$ of that was used with melon extract. The precipitates were stored at $-20^{\circ} \mathrm{C}$ and used for the assay of enzyme activity within a month. The precipitates were redissolved with $5 \mathrm{mM}$ potassium phosphate buffer containing $0.1 \mathrm{mM}$ DTT, and dialyzed with the same buffer. After one more centrifugation at $12000 \times \mathrm{g}$ for $30 \mathrm{~min}$, these crude enzymes were used for assay. The procedure mentioned above was conducted on an ice bath or in a cold room $\left(1 \sim 2^{\circ} \mathrm{C}\right)$ after crushing cells.

Assay of the substrate specificity

The reaction mixture was composed of $5 \mathrm{mg}$ of albumin (bovine), $0.25 \mathrm{mM}$ acyl $\mathrm{CoA}, 20$ $\mathrm{mM}$ alcohol, $0.05 \mathrm{mM}$ DTT, $5 \mathrm{mM}$ potassium phosphate buffer ( $\mathrm{pH} 8.0$ ) and $70 \mu l$ of enzyme solution in a total volume of $500 \mu l$. The reaction mixture was placed into a centrifugation-tube type of Millipore filter (UFC 3 $\mathrm{TGC} 00$ ) and incubated at $30^{\circ} \mathrm{C}$ for $30 \mathrm{~min}$. The optimum conditions of $\mathrm{pH}(8.0)$ and temperature $\left(30^{\circ} \mathrm{C}\right)$ for the enzyme reaction of melon and strawberry were the same as those for the banana judged from tentative experiments. The tube was then cooled in an ice bath and centrifuged to eliminate protein. An aliquot $(100 \mu l)$ of filtrate was injected into a high-performance liquid chromatograph (HPLC) (Hitachi L 6200), and the CoA formed during the reaction was determined ${ }^{5)}$. The reaction mixture without alcohols was used as the blank. When various alcohols were tested as substrate for the enzyme, acetyl CoA was used as the substrate for acid moiety of esters. In the case of testing various acyl CoAs, isobutyl alcohol was used as the substrate. The HPLC conditions were as follows. Column was a reverse phase absorption type (Hitachi gel \#3056, $15 \mathrm{~cm} \times 4 \mathrm{~mm}$ ). Mobile phase was $0.2 \mathrm{M}$ potassium phosphate, monobasic $(\mathrm{pH}$ $4.2)$ including $10 \%(\mathrm{v} / \mathrm{v})$ acetonitrile, and flowed at $0.8 \mathrm{ml} \cdot \mathrm{min}^{-1}$.

\section{Alcohol contents in fruit juice}

Banana pulp was crushed with equal amounts of citrate buffer (0.1 M, pH 3.8) and squeezed with two layers of gauze cloths. The central juicy part of melon or intact strawberry was squeezed with two layers of gauze cloths without the buffer. Because the $\mathrm{pH}$ values of these juices were below 4.0 , the pectinmethylesterase in the juices did not catalyse the change of methoxyl pectin during measurement of alcohol contents ${ }^{6}$. Alcohols in the juices were analyzed with the method of BARTOLOME ${ }^{7}$. One $\mathrm{m} l$ of Juice, $2.5 \mathrm{~m} l$ of $7 \%$ $(\mathrm{v} / \mathrm{v})$ phosphoric acid, and $2.5 \mathrm{ml}$ of $5 \%(\mathrm{w} / \mathrm{v})$ $\mathrm{NaNO}$ were set in a test tube $(10 \mathrm{~cm} \times 12 \mathrm{~mm})$ and capped with silicon immediately. The sample, reagents and test tube were cooled previously in ice. The test tube was vigorously shaken by hand and put into crushed ice for a while (ca. $1 \mathrm{~min}$ ), and the head space gas $(1 \sim 3 \mathrm{ml})$ was injected into a gas chromatograph (GC) (Hitachi 163). The GC conditions was as follows. Ucon oil $1715(15 \%)$ was used as the liquid phase of the column $(2 \mathrm{~m} \times$ $3 \mathrm{~mm}$ ). The carrier gas was nitrogen with a flow rate of $30 \mathrm{ml} \cdot \mathrm{min}^{-1}$. The detector was FID with a flow rate of $30 \mathrm{ml} \cdot \mathrm{min}^{-1}$ of hydrogen and of $800 \mathrm{ml} \cdot \mathrm{min}^{-1}$ of air.

Analysis of volatile esters from fruits

The main volatile esters produced from fruits were analyzed with the following method. Four fingers of halved yellow banana fruits were put into a $6 l$-glass jar. After 2 hours incubation at room temperature, the head space gas $(4 \mathrm{ml})$ was injected into GC with Tween $20(20 \%)$ coated column at $50^{\circ} \mathrm{C}$ or $80^{\circ} \mathrm{C}$. Esters from four halved fruits of melon were analyzed with the same manner. Ten intact fruits of strawberry were placed in a 2.5 l-glass jar. 


\section{Results and Discussion}

Esters produced from the fruits are listed in Table 1. Most of volatiles detected were found to be esters except ethyl alcohol (23.7 $\mu \mathrm{mol} \cdot \mathrm{kg}^{-1} \mathrm{~h}^{-1}$ ) and a negligible amount of acetaldehyde in the banana volatiles. The patterns of ester production obtained by this simple method were well consistent with results in the previous reports ${ }^{1 \sim 3}$. Esters from banana fruit consisted of a range of combination of low molecular alcohols with acetic or butyric acids" ${ }^{11}$. Ethyl acetate was predominant of esters from melon ${ }^{3}$. Methyl esters were mainly produced from strawberry ${ }^{2}$.

Table 2 shows the alcohol specificity of the ester synthetase from banana, melon and strawberry. Isobutyl alcohol, butyl alcohol and isoamyl alcohol showed a higher reactivity for the ester synthetase extracted from these three kinds of fruits. This reactivity had been expected from the effect of administration of alcohols to banana slices in the previous report $^{8)}$. While methyl and ethyl alcohols were rather inert substrates for the enzymes from banana and melon, both alcohols reacted fairly well with the enzyme from strawberry. Although a study concerning ester synthetase from banana fruits was performed previously, this is the first report that concerns the substrate specificity of the enzyme from fruits. The alcohol specificity of the enzyme from these fruits showed a difference from brewers yeast which have a dissimilar characteristics of the specificity ${ }^{9)}$. The enzyme from yeast was least active against propyl alcohol among $\mathrm{C}_{1^{-}}$ $\mathrm{C}_{6}$ alcohols.

Table 3 shows the acyl CoA specificity of the enzyme. Acetyl $\mathrm{CoA}$ showed the highest reactivity for the enzyme from banana and melon. On the other hand, butyryl $\mathrm{CoA}$ and valeryl $\mathrm{CoA}$ were more reactive for the enzyme from strawberry than acetyl CoA. Branched chain acyl CoAs were commonly poorer substrates than straight chain acyl CoAs among these three enzymes. Similar findings have been reported on an enzyme from Neurospora $\mathrm{sp}^{10)}$. But the enzyme from the microorganism did not react with acetyl $\mathrm{CoA}$ and propionyl $\mathrm{CoA}$, showing a totally different nature from enzymes of fruits.

From the fact that straight chain acids,

Table 1 Ester production from banana (cv. Cavendish), melon (cv. Gensung) and strawberry (cv. Hō kō-wase) fruits

\begin{tabular}{|c|c|c|c|}
\hline & Banana & Melon & Strawberry \\
\hline Esters & $\begin{array}{l}\text { ester } \\
\text { emanation } \\
\mu \mathrm{mol} \cdot \mathrm{kg}^{-1} \cdot \mathrm{h}^{-1}(\%)^{*}\end{array}$ & $\begin{array}{l}\text { ester } \\
\text { emanation } \\
\mu \mathrm{mol} \cdot \mathrm{kg}^{-1} \cdot \mathrm{h}^{-1}(\%)\end{array}$ & $\begin{array}{l}\text { ester } \\
\text { emanation } \\
\mu \mathrm{mol} \cdot \mathrm{kg}^{-1} \cdot \mathrm{h}^{-1}(\%)\end{array}$ \\
\hline Methyl acetate & nd & $1.8(13.3)$ & $1.7(74.2)$ \\
\hline Ethyl acetate & $24.0(47.4)$ & $11.5 \quad(84.7)$ & $0.03(1.3)$ \\
\hline Isobutyl acetate & $3.7(7.3)$ & $0.12(0.9)$ & nd \\
\hline Butyl acetate & $10.4(20.6)$ & $0.08(0.6)$ & nd \\
\hline Isoamyl acetate & $5.4(10.7)$ & $0.07(0.5)$ & nd \\
\hline Methyl butyrate & nd & nd & $0.48(21.0)$ \\
\hline Ethyl butyrate & nd & nd & $0.01(0.4)$ \\
\hline Isobutyl butyrate & $2.1(4.2)$ & nd & nd \\
\hline Butyl butyrate & $3.1(6.1)$ & nd & nd \\
\hline Isoamyl butyrate & $1.9(3.8)$ & nd & nd \\
\hline Methyl caproate & nd & nd & $0.07(3.1)$ \\
\hline
\end{tabular}

* Numerals in parentheses are the percentages of the total amounts of ester. nd : non-detectable 
Table 2 Alcohol specificity of ester synthetase from fruits

\begin{tabular}{|c|c|c|c|}
\hline & Banana & Melon & Strawberry \\
\hline Alcohols & $\begin{array}{l}\text { ester } \\
\text { production } \\
\text { nmol } 30 \mathrm{~min}^{-1 *}(\%)^{* *}\end{array}$ & $\begin{array}{l}\text { ester } \\
\text { production } \\
\text { nmol } 30 \mathrm{~min}^{-1}(\%)\end{array}$ & $\begin{array}{l}\text { ester } \\
\text { production } \\
\text { nmol } 30 \mathrm{~min}^{-1}(\%)\end{array}$ \\
\hline Methyl alcohol & $6(3.4)$ & $1(1.4)$ & $15(15.8)$ \\
\hline Ethyl alcohol & $25(14.0)$ & $3(4.1)$ & $20(21.1)$ \\
\hline Propyl alcohol & $103(57.5)$ & $26(35.6)$ & $67(70.5)$ \\
\hline Isobutyl alcohol & $174(97.2)$ & $58(79.5)$ & $48(50.5)$ \\
\hline Butyl alcohol & $133(74.3)$ & $58(79.5)$ & $75(78.9)$ \\
\hline Isoamyl alcohol & $179(100.0)$ & $73(100.0)$ & $95(100.0)$ \\
\hline Amyl alcohol & $3(1.7)$ & $0(0.0)$ & $1(1.1)$ \\
\hline
\end{tabular}

* $\mathrm{nmol}$ of $\mathrm{CoA}$ released for $30 \mathrm{~min}$.

** Numerals in the parentheses are percentages of the value to the most reactive substrate.

Table 3 Acyl CoA specificity of ester synthetase from fruits

\begin{tabular}{|c|c|c|c|}
\hline & Banana & Melon & Strawberry \\
\hline Acyl CoAs & $\begin{array}{l}\text { ester } \\
\text { production } \\
\text { nmol } 30 \mathrm{~min}^{-1 *}(\%)^{* *}\end{array}$ & $\begin{array}{l}\text { ester } \\
\text { production } \\
\text { nmol. } 30 \mathrm{~min}^{-1}(\%)\end{array}$ & $\begin{array}{l}\text { ester } \\
\text { production } \\
\text { nmol } 30 \mathrm{~min}^{-1}(\%)\end{array}$ \\
\hline Acetyl CoA & $174(100.0)$ & $82(100.0)$ & $48(56.5)$ \\
\hline Propionyl CoA & $51(29.3)$ & $57(69.5)$ & $32(37.6)$ \\
\hline Isobutyryl $\mathrm{CoA}$ & $14(8.0)$ & $2(2.4)$ & $13(15.3)$ \\
\hline Butyryl CoA & $52(29.9)$ & $19(23.2)$ & $72(84.7)$ \\
\hline Isovaleryl CoA & $0(0.0)$ & $0(0.0)$ & $5(5.9)$ \\
\hline Valeryl CoA & $3(1.7)$ & $17(20.7)$ & $85(100.0)$ \\
\hline
\end{tabular}

* $\mathrm{nmol}$ of $\mathrm{CoA}$ released for $30 \mathrm{~min}$.

** Numerals in the parentheses are percentages of the value to the most reactive substrate.

Table 4 Alcohol contents of banana, melon and strawberry pulps

\begin{tabular}{|c|c|c|c|}
\hline & Banana & Melon & Strawberry \\
\hline Alcohols & $\begin{array}{l}\text { alcohol } \\
\text { content } \\
\text { mM in pulp }{ }^{*}(\%)^{* *}\end{array}$ & $\begin{array}{c}\text { alcohol } \\
\text { content } \\
\text { mM in pulp }(\%)\end{array}$ & $\begin{array}{c}\text { alcohol } \\
\text { content } \\
\mathrm{mM} \text { in pulp (\%) }\end{array}$ \\
\hline Methyl alcohol & $1.06(7.4)$ & $0.80(7.6)$ & $1.23(70.7)$ \\
\hline Ethyl alcohol & $12.40(86.8)$ & $9.74(92.4)$ & $0.20(11.5)$ \\
\hline Propyl alcohol & $0.17(1.2)$ & nd & $0.12(6.9)$ \\
\hline Isobutyl alcohol & $0.34(2.4)$ & nd & nd \\
\hline Butyl alcohol & $0.19(1.3)$ & nd & $0.12(6.9)$ \\
\hline Isoamyl alcohol & $0.12(0.8)$ & nd & $0.03(1.7)$ \\
\hline Amyl alcohol & nd & nd & $0.04(2.3)$ \\
\hline
\end{tabular}

* $\mathrm{mM}$ in the pulp juice

** Numerals in parentheses are the percentages of the total amounts of alcohol.

nd : non-detectable 
mainly acetic and butyric acids, were observed as acid moieties of volatile esters produced from the fruits as shown in Table 1, the characteristic pattern of acid moieties of esters seems to depend on the acyl CoA specificity of ester synthetase. This idea is also reinforced by the fact that banana fruit produces more butyrate than isobutyrate in spite of about equal amounts of isobutyric and butyric acid contents in pulp ${ }^{11}$.

On the other hand, the alcohol moieties of esters from each fruit was not consistent with the alcohol specificity of the enzyme. For example, melon produced mainly ethyl acetate, whereas ethyl alcohol was not a good substrate for the enzyme.

Alcohol contents in the pulp of fruits were determined (Table 4). Ethyl alcohol was mainly detected in the juices of banana and melon, while methyl alcohol predominated over other alcohols in strawberry. Predominance of ethyl acetate from banana and melon may depend upon the abundant ethyl alcohol in the pulp of both fruits, and also methyl esters produced from strawberry may depend upon the abundant methyl alcohol in the pulp of strawberry. Thus it may be considered that the pattern of alcohol moieties of esters produced from each fruit mainly depends on the amount of alcohols in the pulp.

\section{References}

1) McCarthy, A.I., Palmar, J.K., Shaw, C.P. and ANDERson, E.E. : J. Food Sci., 28, 379 (1963).

2) Dirinck, P.J., Depooter, H.L., Willaert, G.A. and Schamp, N.M.: J. Agric. Food Chem., 29, 316 (1981).

3) Yaвumoto, Y., Yamaguchi, $M$. and Jennings, W.G. : Food Chem., 3, 17 (1978).

4) Harada, M., UEDa, Y. and Iwata, T. : Plant Cell Physiol., 26, 1067 (1985).

5) King, T.M. and Reiss, P.D. : Anal. Biochem., 146, 173 (1985).

6) Hultin, H.O. and Levine, A.S. : Arch. Biochem. Biophys., 101, 396 (1963).

7) Bartolome, L.G. and HoFf, J.E. : $J$. Agric. Food Chem., 20, 262 (1972).
8) Ueda, Y., Ogata, K.: Nippon Shokuhin Kogyo Gakkaishi, 25, 440 (1978).

9) Yoshioka, K. and Hashimoto, N. : Agric. Biol. Chem., 45, 2183 (1981).

10) Yamauchi, H., Hasuo, T., Amachi, T., Akita. O., Hara, S. and Yoshizawa, K. Agric. Biol. Chem., 53, 1551 (1989).

11) Ueda, Y., Minamide, T., Ogata, K. and Yamamoto, T.: Nippon Shokuhin Kogyo Gakkaishi, 17, 545 (1970).

(Received Mar. 13, 1991)

果実（パナナ, メロン，イチゴ）よりのエステル香気生 成パターンとェステル生成酳素の基質特異性ならひに アルコール含量との関係について

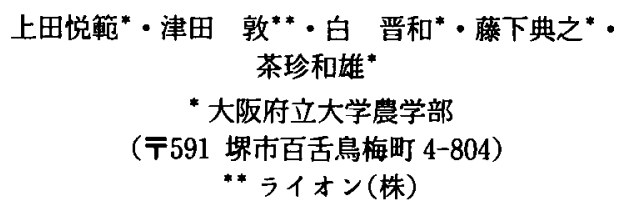

バナナ,メロンおよびイチゴ果実より生成する揮発性 エステルをへッドスペースガスを分析することで調べた。 バナナの場合はエチルおよびブチルェステルが主として みられ、イソブチル，イソアミルェステルがそれに続い た.メロンでは主にエチルェステルがみられ，イチゴで は主にメチルエステルがみられた。また，三種の果実と あ，主に酢酸エステル，酪酸エステルがみられた。

エステル生成酵素をこれらの果実より抽出した，プロ ピル，イソブチル，ブチル， イソアミル各アルコールに 対して抽出した酳素は高い反応性を示したが，メチル， エチル，アミル各アルコールに対しては反応性が低かっ た。 バナナ、メロンからの䤃はアセチル CoA, プロ ピオニル $\mathrm{CoA}$, フチリル $\mathrm{CoA}$ 上く反応し，イチコ の酵素はさらにバレリル CoA ともよく反応した，分枝 したイッブチル CoA，イソアミル CoAに対してはあ まり反応しなかった．果肉中のアルコール含量はバナナ， メロンでは主にエチルアルコールが高く，イチコではメ チルアルコールが高かった。

以上の結果より，果実の生成するエステルについて， そのアルコール残基は主に果肉のアルコール含量を反映 し，酸残基は主にエステル生成醉素の基質特異性にあと ずいていると推察した。 